\title{
Effects of Nitrogen Treatment on Growth Characteristics in Moso Seedling
}

\author{
Li J*, Gao J, Gao Hy, Zhang Bs and Shi L \\ International Centre for Bamboo and Rattan, China \\ *Corresponding author: Li J, International Centre for Bamboo and Rattan, China
}

\begin{tabular}{|c|c|}
\hline ARTICLE INFO & ABSTRACT \\
\hline $\begin{array}{l}\text { Received: February 02, } 2019 \\
\text { Published: 业 March 08, } 2019\end{array}$ & $\begin{array}{l}\text { The changes of photosynthetic efficiency and growth characteristics of bamboo seedling } \\
\text { were studied under different nitrogen treatments, and the optimal nitrogen concentration }\end{array}$ \\
\hline $\begin{array}{l}\text { Citation: Li J, Gao J, Gao Hy, Zhang Bs } \\
\text { Shi L. Effects of Nitrogen Treatment on } \\
\text { Growth Characteristics in Moso Seed- } \\
\text { ling. Biomed J Sci \& Tech Res 15(4)- } \\
\text { 2019. BJSTR. MS.ID.002734. } \\
\text { Keywords: Moso Seedling; Nitrogen; } \\
\text { Response }\end{array}$ & $\begin{array}{l}\text { show that: the nitogen response value of height and root length in } 0.5 \mathrm{mmol} / \mathrm{L}, 1 \mathrm{mmol} / \mathrm{L} \\
\text { treatment is significantly higher than the other treatment }(\mathrm{P}<0.05) \text {, photosynthetic } \\
\text { index }\left(\mathrm{P}_{\mathrm{n}^{\prime}}, \mathrm{T}_{\mathrm{r}^{\prime}}, \mathrm{g}_{\mathrm{s}}\right) \text {, total biomass, stem biomass and stem and root nitrogen use efficiency } \\
\text { in } 0.5 \mathrm{mmol} / \mathrm{L}, 1 \mathrm{mmol} / \mathrm{L} \text { is significantly higher than control, and other treatment }(\mathrm{P} \\
<0.05) \text {, while tendency for } 2 \mathrm{mmol} / \mathrm{L} \text { was significantly lower than other treatment }(\mathrm{P}< \\
\text { 0.05), The results indicated that the growth of the bamboo seedling was promoted in } 0.5 \\
\text { mmol/L and } 1 \mathrm{mmol} / \mathrm{L} \text { nitrogen treatment, but it will be inhibited with the treatment } \\
\text { concentration continued. there are significantly linear relationship between total nitrogen } \\
\text { content and root length, fresh weight, } \mathrm{P}_{\mathrm{n}^{\prime}}, \mathrm{F}_{\mathrm{v}} / \mathrm{F}_{\mathrm{m}^{\prime}}, \mathrm{T}_{\mathrm{r}^{\prime}} \mathrm{g}_{\mathrm{s}^{\prime}} \text { respectively. It showed that compared } \\
\text { with the control, photosynthetic capacity of bamboo seedling was enhanced after nitrogen } \\
\text { treatment ,it will affect plant growth and biomass accumulation and the seedling growth } \\
\text { was restrained in } 2 \mathrm{mmol} / \mathrm{L} \text { nitrogen treatment. }\end{array}$ \\
\hline
\end{tabular}

\section{Introduction}

Nitrogen is the most important nutrient factor in plant growth [1]. Application of nitrogen can affect plant nitrogen metabolism, photosynthetic apparatus and energy distribution, respiratory metabolism, etc. The ultimate manifestation of these physiological metabolisms is the growth pattern of plants and biomass. However, the concentration of nitrogen fertilization affects plant growth [2] and the reasonable application of nitrogen fertilizer will promote the growth of plants [3-6]. Therefore, the study on the effects of nitrogen on the growth of different plants has attracted more and more attention. Moso bamboo is an important economic bamboo species in China, nutrient absorption laws in different developmental stages [7] of moso bamboo has been studied in recent years [8-12]. The results show that when nitrogen supply is sufficient, bamboo depends mainly on improving nutrient content to maintain life activities. When nitrogen is poor, it adapts to environment changes mainly by increasing nutrient resorption. However, these results are based on data obtained from field trials, and different ages plants have a greater impact on nitrogen uptake and transport [13]. There is no report on the demand for nitrogen fertilizer in bamboo seedlings only Shao JF [14] studied the hydroponic system of bamboo seedlings, it's found that the application of nitrate nitrogen is more suitable for bamboo seedlings growth.

Therefore, it is important to determine the nitrogen fertilizer concentration avoid the excess nitrogen addition for bamboo seedlings cultivation [15]. In this study, the photosynthetic efficiency and growth characteristics of moso bamboo seedling were determined, the effects of total nitrogen content and nitrogen absorption and translocation efficiency of moso bamboo seedling under different nitrogen treatments were analyzed and the optimum nitrogen fertilizer concentration for moso bamboo seedling cultivation was determined. It provide a theoretical support for moso bamboo seedling breeding technology.

\section{Material and Method}

\section{Plant Culture and Experimental Treatment}

Collect 500 new seeds of moso bamboo, peel off the seed coat, soak it in cold water for 48 hours, rinse the tap water and wash it, wash off the excess detergent, rinse it with water for $0.5-1 \mathrm{~h}$, then wash it with distilled water. Put it into a clean bench, soak it in 0.5 \%-0.8 \% formaldehyde for 4-6 h, sterilize the seeds evenly after 
shaking for several times, rinse it with sterile water 4 times after sterilization, put it on the water-impregnated filter paper, and put it in the dark and germinate at $25^{\circ} \mathrm{C}$. After the seeds were germinated, they were sown in clean, moist quartz sand in March 27, 2017. After 15 days, the seedlings with the same growth were selected and transplanted to a $1 / 2$ concentration Hoagland nutrient solution: 0.5 mmolL-1P was supplied with $\mathrm{KH}_{2} \mathrm{PO}_{4}, 3 \mathrm{mmolL}^{-1}$ was supplied with $\mathrm{KNO}_{3}$ and $\mathrm{KH}_{2} \mathrm{PO}_{4}, 2.5 \mathrm{mmolL}^{-1} \mathrm{Ca}$ was supplied with $\mathrm{Ca}\left(\mathrm{NO}_{3}\right) \cdot 2 \mathrm{H}_{2} \mathrm{O}$, 1.0 mmolL-1 Mg was supplied with $\mathrm{MgSO}_{4}$, and the micronutrients were $\quad 46.26 \mu \mathrm{molL}^{-1} 1 \mathrm{~B}\left(\mathrm{H}_{3} \mathrm{BO}_{3}\right), \quad 20.06 \mu \mathrm{molL}^{-1} \mathrm{Fe}(\mathrm{EDTA}-\mathrm{Fe})$,

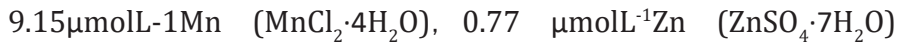
, $0.32 \mu \mathrm{molL}^{-1} \mathrm{Cu}\left(\mathrm{CuSO}_{4} \cdot 5 \mathrm{H}_{2} \mathrm{O}\right)$ and $0.39 \mu \mathrm{molL}^{-1} \mathrm{Mo}\left(\mathrm{H}_{2} \mathrm{MoO}_{4} \cdot 4 \mathrm{H}_{2} \mathrm{O}\right)$. $\mathrm{NH}_{4} \mathrm{NO}_{3}$ was added for different concentrations of $\mathrm{N}$ treatment. The treatment concentrations were $2 \mathrm{mmol} / \mathrm{L}, 1.5 \mathrm{mmol} / \mathrm{L}, 1 \mathrm{mmol} / \mathrm{L}$, and $0.5 \mathrm{mmol} / \mathrm{L}$, respectively. The control $\mathrm{CK}$ did not add $\mathrm{NH}_{4} \mathrm{NO}_{3}$. Each of the bamboo seedlings was treated with 20 plants, each plant was numbered, the nutrient solution was continuously ventilated by the same pump. The $\mathrm{p}^{\mathrm{H}}$ of all treated nutrient solutions was adjusted with a $\mathrm{p}^{\mathrm{H}}$ meter and $0.1 \mathrm{molL}^{-1} \mathrm{NaOH}$ or $0.1 \mathrm{molL}^{-1} \mathrm{HCL}$ to keep it at around 7.35, and the nutrient solution of different treatment concentrations were changed in two days.

\section{Determination of Seedling Height, Root Length, Internode Length, Biomass and Water Content}

From April 10, 2017 (initial stage of treatment) to May 10 (end stage of treatment), each seedling was measured every 3 days, including seedling height, root length, first internode length, second internode length, and third internode length. The seedlings were treated with different nitrogen concentration, and fresh weight of the roots, stems and leaves was measured(W1), the leaves were gently wiped with a wet gauze, and the roots were washed with deionized water and then blotted with absorbent paper. After being killed $\left(105^{\circ} \mathrm{C}, 30\right.$ minutes), it is dried to constant weight at $70^{\circ} \mathrm{C}$, and the dry weight of roots, stems and leaves (W2) is measured. Water content $=(\mathrm{W} 1-\mathrm{W} 2) / \mathrm{W} 1 * 100 \%$.

\section{Determination of Photosynthesis Index}

After the treatment, 3 5 pieces leaves with relatively uniform light were selected The net photosynthetic rate $\left(\mathrm{P}_{\mathrm{n}}\right)$ and Maximum photochemical efficiency $\left(\mathrm{F}_{\mathrm{v}} / \mathrm{F}_{\mathrm{m}}\right)$ of the leaves were determined by Li-COR6400 portable photosynthetic apparatus (Li-COR, USA) and ultra-portable chlorophyll fluorescence instrument Mini-PAM (WALZ, Germany) from 9:00 to 11:30. The experiment was controlled at room temperature of $25^{\circ} \mathrm{C}$, light intensity of $800 \mu \mathrm{mol} \cdot \mathrm{m}^{-2} \cdot \mathrm{s}^{-1}$, and reference chamber $\mathrm{CO}_{2}$ concentration of 380 $\mathrm{mol} \cdot \mathrm{L}^{-1}$. Three replicate plants were determined, and three leaves were selected per plant, and the results were averaged.

\section{Determination and Calculation of Nitrogen-Related Index of Bamboo Seedlings After Nitrogen Treatment}

a) Determination of total nitrogen content: After treatment, different concentrations of seedlings were collected, and the total nitrogen content of roots, stems and leaves was determined by $\mathrm{H}_{2} \mathrm{SO}_{4}-\mathrm{H}_{2} \mathrm{O}_{2}$ digestion method.

b) Nitrogen response value of seedling height = (end-stage seedling height after nitrogen treatment - end-stage seedling height of CK) / end-stage seedling height of CK c) Nitrogen response value of seedling root length $=$ (endstage root length after nitrogen treatment - end-stage root length of CK) / end-stage root length of CK

d) Nitrogen use efficiency (\%) = dry weight / total nitrogen content $\times 100 \%$.

\section{Statistical and Data Analyses}

Use Excel 2007 and SPSS14.0 to perform statistical analysis, use one-way ANOVA and LSD for variance analysis and multiple comparisons $(\alpha=0.05)$ and uselinear regression for correlation analysis. The data in the chart are mean value \pm standard deviation.

\section{Results}

\section{The Growth Characterics After Nitrogen Treatment in Moso Seedlings}
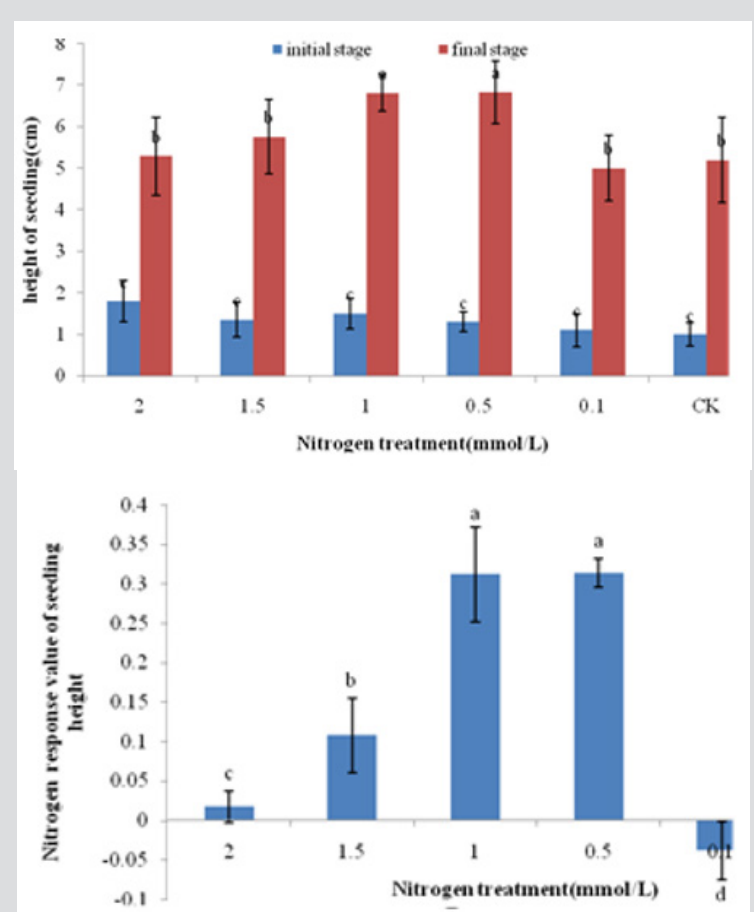

Figure 1: Variation of height characters after nitrogen treatment in moso seedlings.

Note: Different small letters meant significant difference among different nitrogen treatment at 0.05 level. The same below.

As Figure 1 shown, From the initial stage to the end of the treatment, the seedling height and root length of bamboo were gradually increased. Studies have shown that in the initial stage of treatment, the difference in seedling height of bamboo seedling was not significant, and the final seedling height was significantly higher after treatment at $0.5 \mathrm{mmol} / \mathrm{L}$ and $1 \mathrm{mmol} / \mathrm{L}$ than other treatments. The seedling height in final stage increased by $193.89 \%$, $402.30 \%, 354.67 \%, 437.91 \%, 739.58 \%$ and $451.85 \%$ with the treatment concentration from high to low, respectively. Among them, $0.1 \mathrm{mmol} / \mathrm{L}$ had the highest seedling height increase rate, and $2 \mathrm{mmol} / \mathrm{L}$ had the lowest seedling height increase rate after treatment. The calculation results of nitrogen response to seedling height showed that the nitrogen response of bamboo seedling after 
treatment at $0.5 \mathrm{mmol} / \mathrm{L}$ and $1 \mathrm{mmol} / \mathrm{L}$ was significantly higher than that of other treatments. As Figure 2 shown, at the beginning of the treatment, there was no significant difference in root length of bamboo seedlings with different nitrogen treatments.
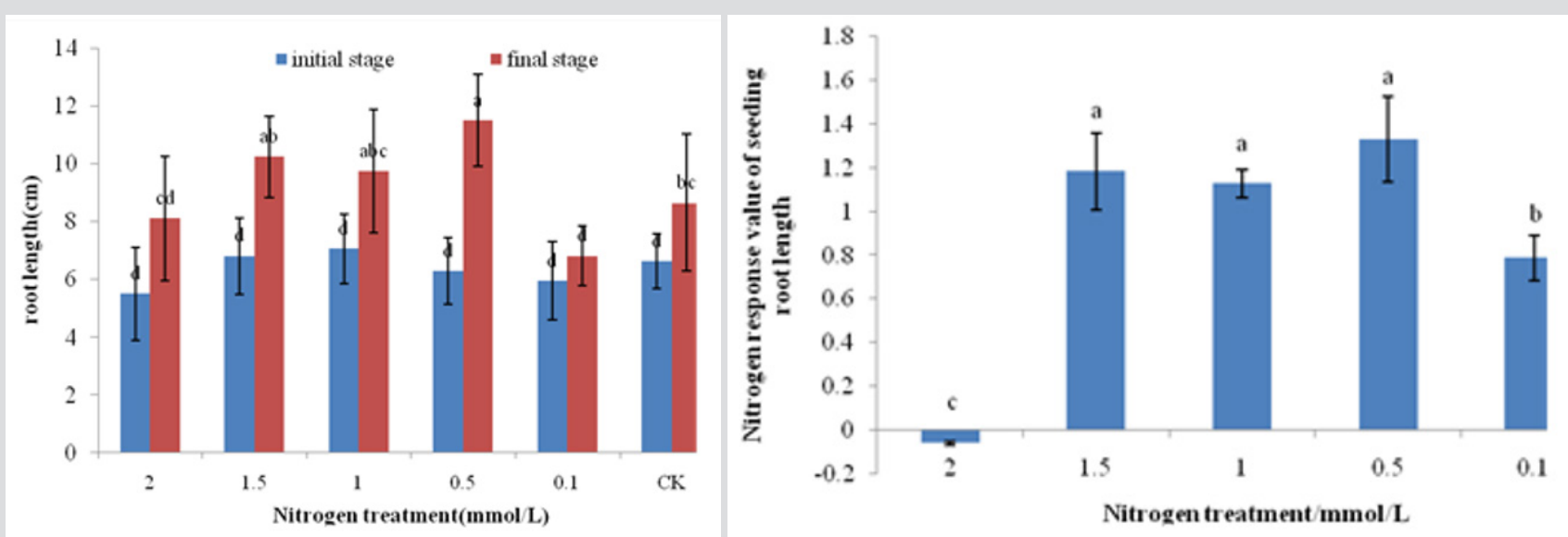

Figure 2: Variation of root length characters after nitrogen treatment in moso seedlings.

The final root length with $0.5 \mathrm{mmol} / \mathrm{L}$ treatment was significantly higher than other treatments. The root length in end stage increased by $47.27 \%, 50.42 \%, 92.43 \%, 82.62 \%, 90.91 \%$ and $13.47 \%$ with the treatment concentration from high to low. 0.1 $\mathrm{mmol} / \mathrm{L}, 0.5 \mathrm{mmol} / \mathrm{L}$ and $1.0 \mathrm{mmol} / \mathrm{L}$ treatment root length had the highest seedling height increase rate. Nitrogen response of root length showed that the nitrogen response of root length with 1.5 $\mathrm{mmol} / \mathrm{L}, 1.0 \mathrm{mmol} / \mathrm{L}$ and $0.5 \mathrm{mmol} / \mathrm{L}$ treatment was significantly higher than other treatments. Studies have shown that with the increase of nitrogen treatment, the growth of bamboo seedlings first increases and then decreases. The seedling height and root length of the bamboo seedlings with $0.5 \mathrm{mmol} / \mathrm{L}$ and $1 \mathrm{mmol} / \mathrm{L}$ treatment were higher. The growth of bamboo seedling was significantly inhibited after $2 \mathrm{mmol} / \mathrm{L}$ treatment. The internode elongation rate of bamboo seedling was counted from the initial stage to the end stage in Figure 3. After the $2 \mathrm{mmol} / \mathrm{L}$ nitrogen treatment, the first internode length of the bamboo seedling was longer and the elongation rate was faster. The length between the second and third sections is shorter and the elongation speed tends to be gentle.

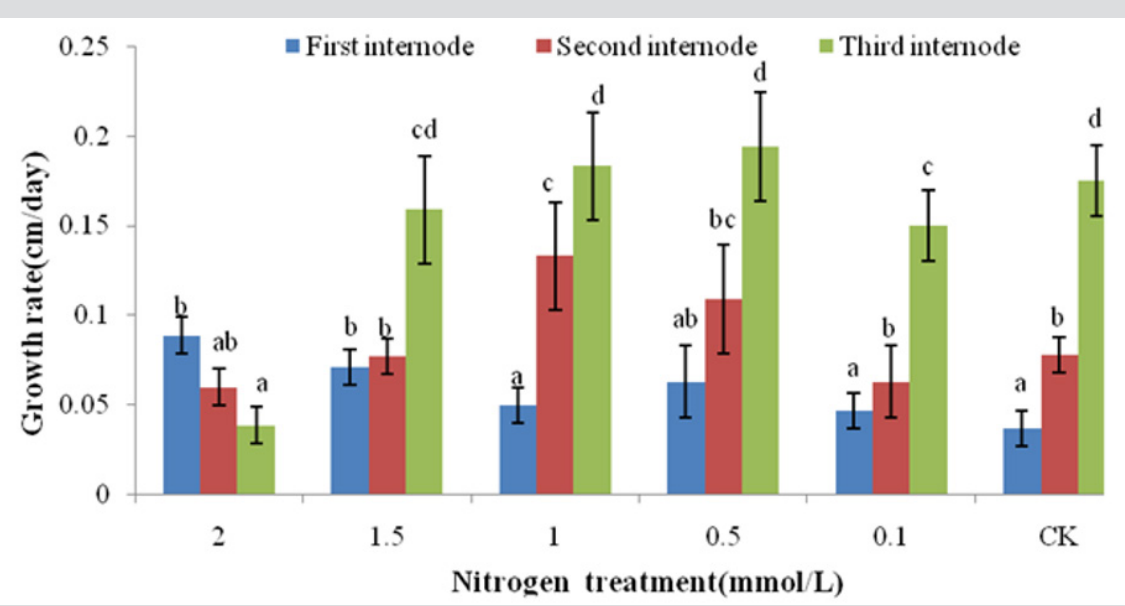

Figure 3: Growth rate of internode after nitrogen treatment in moso seedlings ( $\mathrm{cm} /$ day).

Table 1: Biomass and water content after nitrogen treatment in moso seedlings.

\begin{tabular}{|c|c|c|c|c|c|}
\hline Nitrogen Treatments & Root Biomass/g & Stem Biomass/g & Leaf Biomass/g & Total Biomass/g & Root/shoot Ratio \\
\hline $2 \mathrm{mmol} / \mathrm{L}$ & $0.77 \pm 0.02 \mathrm{~b}$ & $0.49 \pm 0.02 \mathrm{a}$ & $0.49 \pm 0.06 \mathrm{a}$ & $1.74 \pm 0.02 \mathrm{a}$ & 0.79 \\
\hline $1.5 \mathrm{mmol} / \mathrm{L}$ & $0.6 \pm 0.04 \mathrm{ab}$ & $0.91 \pm 0.10 \mathrm{~b}$ & $0.43 \pm 0.10 \mathrm{a}$ & $1.94 \pm 0.60 \mathrm{ab}$ & 0.45 \\
\hline $1 \mathrm{mmol} / \mathrm{L}$ & $0.89 \pm 0.02 \mathrm{~b}$ & $1.34 \pm 0.06 \mathrm{c}$ & $0.49 \pm 0.02 \mathrm{a}$ & $2.48 \pm 0.06 \mathrm{c}$ & 0.48 \\
\hline $0.5 \mathrm{mmol} / \mathrm{L}$ & $0.69 \pm 0.02 \mathrm{~b}$ & $1.13 \pm 0.10 \mathrm{~b}$ & $0.45 \pm 0.04 \mathrm{a}$ & $2.08 \pm 0.10 \mathrm{~b}$ & 0.44 \\
\hline $0.1 \mathrm{mmol} / \mathrm{L}$ & $0.83 \pm 0.04 \mathrm{~b}$ & $0.83 \pm 0.04 \mathrm{~b}$ & $0.47 \pm 0.02 \mathrm{a}$ & $2.13 \pm 0.04 \mathrm{~b}$ & 0.44 \\
\hline $\mathrm{CK}$ & $0.49 \pm 0.04 \mathrm{a}$ & $1.04 \pm 0.04 \mathrm{~b}$ & $0.38 \pm 0.02 \mathrm{a}$ & $2.11 \pm 0.04 \mathrm{~b}$ & 0.34 \\
\hline
\end{tabular}

Note: Different small letters in the same line meant significant difference among different nitrogen treatment at 0.05 level. The same below. 
The other treatments were opposite to the $2 \mathrm{mmol} / \mathrm{L}$ treatment results. The growth of the first internode was shorter and the elongation rate was slower, but the growth was faster and longer during the second and third internodes.in $0.1 \mathrm{mmol} / \mathrm{L}, 0.5$ $\mathrm{mmol} / \mathrm{L}, 1.0 \mathrm{mmol} / \mathrm{L}$ and $1.5 \mathrm{mmol} / \mathrm{L}$ treatment (Table 1).

The total biomass, root, stem and leaf biomass of moso bamboo seedlings at the end of the stage are shown in Table 2. The total biomass and stem biomass of bamboo seedling after $1 \mathrm{mmol} / \mathrm{L}$ treatment were the highest among all the treatment and the index of the total biomass were consistent to the stem biomass. When the treatment concentration continued to increase, the total biomass and stem biomass began to decrease, and the value was the lowest after $2 \mathrm{mmol} / \mathrm{L}$ treatment. The leaf biomass with difference treatment were not significant. Root biomass values with CK were significantly lower than other treatments. Root/shoot ratio was the highest after treatment with $2 \mathrm{mmol} / \mathrm{L}$, and the control group was the lowest. The results showed that the total biomass, stem and root biomass of the bamboo seedlings were the highest after $1 \mathrm{mmol} / \mathrm{L}$ treatment, and root/shoot ratio was larger when the nitrogen treatment concentration was higher.

Table 2: Variation of photosythetic characters after nitrogen treatment in moso seedlings.

\begin{tabular}{|c|c|c|c|c|}
\hline Nitrogen Treatment & $P_{n} /\left(\mu\right.$ molco $\left._{2} m^{-2} s^{-2}\right)$ & $T_{r} /\left(\mathrm{mmolh}_{2} \mathrm{om}^{-2} \mathrm{~s}^{-2}\right)$ & Gs $\left(\mathrm{molh}_{2} \mathrm{om}^{-2} \mathrm{~s}^{-2}\right)$ & $\mathrm{Fv} / \mathrm{fm}$ \\
\hline $2 \mathrm{mmol} / \mathrm{L}$ & $1.07 \pm 0.01 \mathrm{~b}$ & $0.14 \pm 0.01 \mathrm{c}$ & $0.16 \pm 0.01 \mathrm{c}$ & $0.75 \pm 0.02 \mathrm{ab}$ \\
\hline $1.5 \mathrm{mmol} / \mathrm{L}$ & $1.59 \pm 0.03 \mathrm{a}$ & $0.37 \pm 0.00 \mathrm{~b}$ & $0.21 \pm 0.01 \mathrm{~b}$ & $0.79 \pm 0.01 \mathrm{a}$ \\
\hline $1 \mathrm{mmol} / \mathrm{L}$ & $1.52 \pm 0.02 \mathrm{a}$ & $0.63 \pm 0.02 \mathrm{a}$ & $0.36 \pm 0.03 \mathrm{a}$ & $0.80 \pm 0.02 \mathrm{a}$ \\
\hline $0.5 \mathrm{mmol} / \mathrm{L}$ & $1.66 \pm 0.14 \mathrm{a}$ & $0.59 \pm 0.01 \mathrm{a}$ & $0.35 \pm 0.03 a$ & $0.81 \pm 0.01 \mathrm{a}$ \\
\hline $0.1 \mathrm{mmol} / \mathrm{L}$ & $1.21 \pm 0.04 \mathrm{~b}$ & $0.35 \pm 0.01 b$ & $0.22 \pm 0.01 b$ & $0.76 \pm 0.01 \mathrm{ab}$ \\
\hline $\mathrm{CK}$ & $1.13 \pm 0.05 b$ & $0.28 \pm 0.01 \mathrm{c}$ & $0.21 \pm 0.01 \mathrm{c}$ & $0.78 \pm 0.01 \mathrm{a}$ \\
\hline
\end{tabular}

Changes in Photosynthesis of Moso Seedlings After Nitrogen Treatment

As Table 2 shown, the photosynthesis parameters of moso bamboo leaves with different treatments were significant. The net photosynthetic rate $\mathrm{P}_{\mathrm{n}}$ were significantly higher at $1.5 \mathrm{mmol} / \mathrm{L}$, $1 \mathrm{mmol} / \mathrm{L}$ and $0.5 \mathrm{mmol} / \mathrm{L}$ than other treatments , and the difference of these three treatments was not significant. The transpiration rate $T_{r}$ and the stomatal conductance $g_{s}$ have trends with different treatment. The $\mathrm{T}_{\mathrm{r}}$ value and $\mathrm{g}_{\mathrm{s}}$ value were significantly higher at 0.5 $\mathrm{mmol} / \mathrm{L}$ and $1 \mathrm{mmol} / \mathrm{L}$ than other treatments. The $\mathrm{T}_{\mathrm{r}}$ value and $\mathrm{g}_{\mathrm{s}}$ value at $2 \mathrm{mmol} / \mathrm{L}$ treatment were significantly lower than other treatments. The maximum photochemical efficiency $\left(\mathrm{F}_{\mathrm{v}} / \mathrm{F}_{\mathrm{m}}\right)$ of PSII was the highest after $0.5 \mathrm{mmol} / \mathrm{L}$ and $1 \mathrm{mmol} / \mathrm{L}$ treatment , but the difference between different nitrogen treatments was not significant. The results showed that with the increase of nitrogen concentration, $P_{n}, T_{r^{\prime}} g_{s}$ and $F_{v} / F_{m}$ of bamboo seedlings increased first and then decreased, and the photosynthesis parameters were highest with $1 \mathrm{mmol} / \mathrm{L}$ and $0.5 \mathrm{mmol} / \mathrm{L}$ treatment.

\section{The Absorption and Transportation Efficiency of Nitrogen in Moso Seedlings}

The nitrogen content and nitrogen use efficiency of different tissues and organs of different treatments were significantly different (Table 3). The total nitrogen content was higher in the high-nitrogen treatment in roots, stems and leaves $(2 \mathrm{mmol} / \mathrm{L}, 1.5$ $\mathrm{mmol} / \mathrm{L}, 1 \mathrm{mmol} / \mathrm{L})$, lower in low-nitrogen treatment $(0.5 \mathrm{mmol} / \mathrm{L}$, $0.1 \mathrm{mmol} / \mathrm{L}, \mathrm{CK}$ ).While the root and stem use efficiency was significantly higher at $0.5 \mathrm{mmol} / \mathrm{L}$ treatment than other treatments. Under different treatments, the nitrogen use efficiency of roots and leaves was lower than that of stems, and there was no obvious rule between different treatments.

Table 3: The absorption and transportation efficiency of nitrogen in moso seedlings.

\begin{tabular}{|c|c|c|c|}
\hline Organs & Nitrogen Treatment & Total Nitrogen Content/g & Nitrogen Use Effientcy/\% \\
\hline \multirow{6}{*}{ root } & $2 \mathrm{mmol} / \mathrm{L}$ & $104.57 \pm 14.58 \mathrm{c}$ & $0.12 \pm 0.02 b$ \\
\hline & $1.5 \mathrm{mmol} / \mathrm{L}$ & $123.72 \pm 15.22 \mathrm{~d}$ & $0.07 \pm 0.01 \mathrm{a}$ \\
\hline & $1 \mathrm{mmol} / \mathrm{L}$ & $115.15 \pm 22.13 \mathrm{~cd}$ & $0.07 \pm 0.01 \mathrm{a}$ \\
\hline & $0.5 \mathrm{mmol} / \mathrm{L}$ & $75.28 \pm 9.16 \mathrm{a}$ & $0.22 \pm 0.02 b$ \\
\hline & $0.1 \mathrm{mmol} / \mathrm{L}$ & $64.67 \pm 5.89 \mathrm{a}$ & $0.14 \pm 0.01 \mathrm{a}$ \\
\hline & $\mathrm{CK}$ & $94.67 \pm 6.43 \mathrm{~b}$ & $0.14 \pm 0.02 \mathrm{a}$ \\
\hline \multirow{6}{*}{ stem } & $2 \mathrm{mmol} / \mathrm{L}$ & $104.57 \pm 19.23 b$ & $0.28 \pm 0.03 a$ \\
\hline & $1.5 \mathrm{mmol} / \mathrm{L}$ & $101.14 \pm 18.13 b$ & $0.28 \pm 0.01 \mathrm{a}$ \\
\hline & $1 \mathrm{mmol} / \mathrm{L}$ & $104.86 \pm 23.16 b$ & $0.35 \pm 0.02 \mathrm{a}$ \\
\hline & $0.5 \mathrm{mmol} / \mathrm{L}$ & $58.55 \pm 7.65 \mathrm{a}$ & $0.56 \pm 0.02 \mathrm{~b}$ \\
\hline & $0.1 \mathrm{mmol} / \mathrm{L}$ & $69.5 \pm 9.11 \mathrm{a}$ & $0.39 \pm 0.01 \mathrm{a}$ \\
\hline & $\mathrm{CK}$ & $65.11 \pm 3.87 a$ & $0.40 \pm 0.02 \mathrm{a}$ \\
\hline \multirow[t]{3}{*}{ leaf } & $2 \mathrm{mmol} / \mathrm{L}$ & $143.14 \pm 15.44 d$ & $0.13 \pm 0.01 \mathrm{a}$ \\
\hline & $1.5 \mathrm{mmol} / \mathrm{L}$ & $105.71 \pm 23.22 \mathrm{c}$ & $0.08 \pm 0.01 \mathrm{a}$ \\
\hline & $1 \mathrm{mmol} / \mathrm{L}$ & $104.29 \pm 6.32 c$ & $0.14 \pm 0.01 \mathrm{a}$ \\
\hline
\end{tabular}




\begin{tabular}{|c|c|c|c|}
\hline & $0.5 \mathrm{mmol} / \mathrm{L}$ & $54.73 \pm 9.87 \mathrm{a}$ & $0.23 \pm 0.02 \mathrm{~b}$ \\
\hline & $0.1 \mathrm{mmol} / \mathrm{L}$ & $82.67 \pm 7.43 \mathrm{~b}$ & $0.22 \pm 0.01 \mathrm{~b}$ \\
\hline & $\mathrm{CK}$ & $62 \pm 10.11 \mathrm{a}$ & $0.18 \pm 0.02 \mathrm{ab}$
\end{tabular}

\section{Discussion}

In this study, low nitrogen promoted the growth of moso bamboo seedling, but the root growth rate of bamboo seedling decreased when the concentration of nitrogen treatment reached $1.5 \mathrm{mmol} / \mathrm{L}$, and the increasing rate of seedling height decreased at $2 \mathrm{mmol} / \mathrm{L}$, which indicated that excessive nitrogen fertilizer first inhibited root growth, and then inhibit the growth of the whole plant if the nitrogen fertilizer continued increased [16]. High concentration ( $2 \mathrm{mmol} / \mathrm{L}, 1.5 \mathrm{mmol} / \mathrm{L}$ ) nitrogen treatment significantly inhibited the elongation between the second and third internodes of the bamboo seedling and promoted the elongation between the first internodes. On the contrary, low concentration ( $1 \mathrm{mmol} / \mathrm{L}, 0.5 \mathrm{mmol} / \mathrm{L}, 0.1 \mathrm{mmol} / \mathrm{L}, \mathrm{CK}$ ) nitrogen treatment promoted the elongation between the second and third internodes. It indicated that it can absorb more nitrogen fertilizer and synthesize more protein under the high nitrogen treatment of the bamboo seedling in the early stage, With the prolongation of treatment time, high nitrogen inhibits the division and growth of plants, while low nitrogen concentration is suitable for the growth of bamboo seedlings and promote its growth. Nitrogen application can significantly improve the potential photosynthetic capacity ,respiratory metabolism, and ultimately affect the establishment of plant growth morphology and biosynthesis of the bamboo seedling. Regression analysis showed that the total nitrogen content of bamboo seedling after treatment was significantly correlated with root length, fresh weight, $\mathrm{F}_{\mathrm{v}} / \mathrm{F}_{\mathrm{m}^{\prime}}, \mathrm{T}_{\mathrm{r}}$ and $\mathrm{g}_{\mathrm{s}}$. The values of $\mathrm{P}_{\mathrm{n}}, \mathrm{T}_{\mathrm{r}}$ and $\mathrm{g}_{\mathrm{s}}$ increased with the increase of nitrogen concentration, because nitrogen directly affects the nitrogen metabolism, photosynthetic apparatus and energy distribution of plants, and the appropriate amount of nitrogen increases the nitrogen uptake of respiratory metabolism, which is beneficial to photosynthesis and carbohydrate synthesis [17-19] regulating photorespiration-related indices [2021], while excessive nitrogen application inhibits photosynthesis of moso bamboo seedlings and inhibits their growth (Figure 4). In this study, the bsiomass of bamboo seedlings was dominated by stalks because plants can induce the distribution of nutrients to larger above-ground organs [12]. Ye Jing's research on Dendrocalamopsis oldhami (Munro)Keng and Bambusa textilis McClure showed that the distribution rate of Dendrocalamopsis oldhami (Munro) Keng stalk biomass was more than half [22], which was consistent with the results of this study.
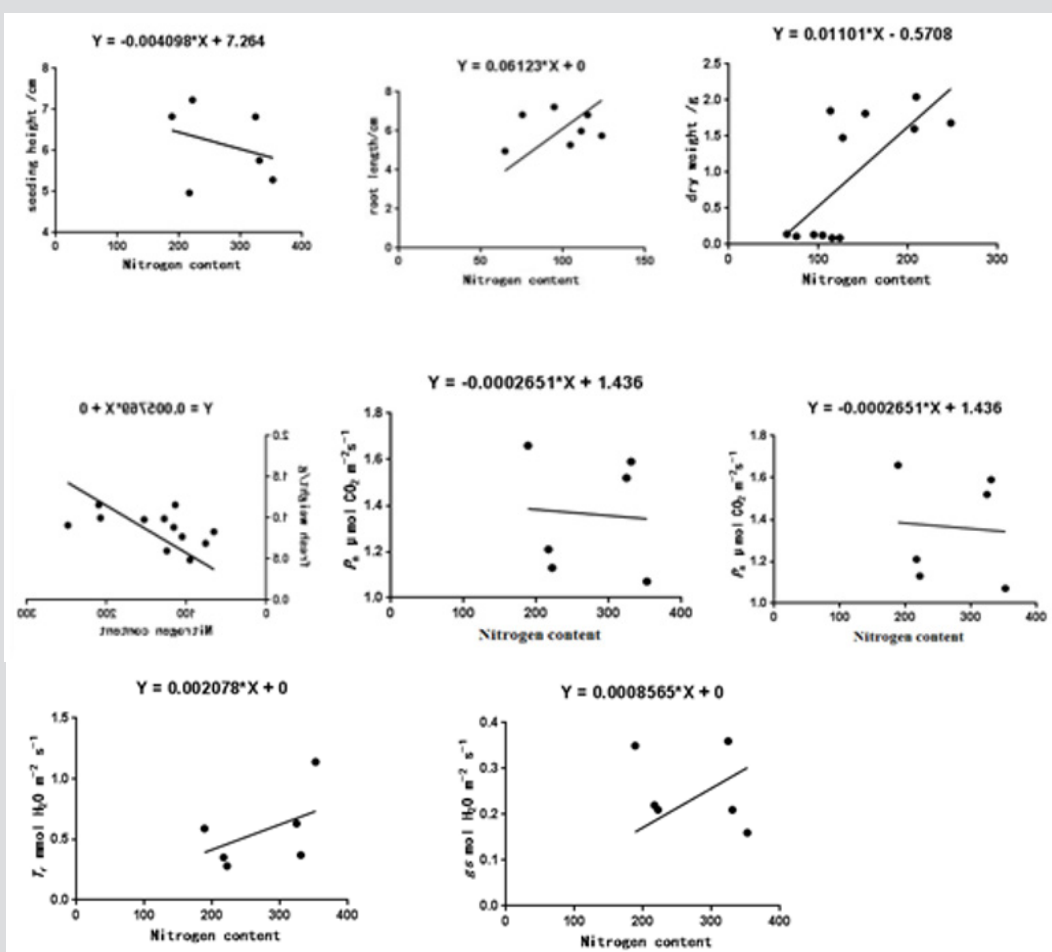

Figure 4: Linear regression between total nitrogen content and growth, photosynthetic characters in moso seedlings.

The high-concentration nitrogen treatment $(2 \mathrm{mmol} / \mathrm{L}, 1.5$ $\mathrm{mmol} / \mathrm{L}$ ) of the bamboo seedlings has a high root-shoot ratio and high total nitrogen content. However, the nitrogen utilization efficiency of bamboo shoots is higher at low concentration of nitrogen treatment $(1 \mathrm{mmol} / \mathrm{L}, 0.5 \mathrm{mmol} / \mathrm{L}, 0.1 \mathrm{mmol} / \mathrm{L})$.Because nitrogen is the largest of all mineral nutrients [23] that affects root morphology, growth and its distribution in the medium. Plants have the root system into the nutrient-rich area to maximize the use of limited nutrient resources [24]. As a result, the nitrogen uptake rate of the root system increases, and the root-shoot ratio increases. At 
the same time, correlation analysis showed that the total nitrogen content was significantly correlated with root growth, which also fully explained the sensitivity of roots to nitrogen utilization [2526]. However, it was found that nitrogen can be efficiently absorbed by high-nitrogen treatment ( $2 \mathrm{mmol} / \mathrm{L}, 1.5 \mathrm{mmol} / \mathrm{L}$ ), but it cannot be used efficiently. The results of the effects of nitrogen were consistent to maize seedling growth, root morphology and nitrogen uptake and utilization efficiency [27].

\section{Conclusion}

Nitrogen application promoted the growth of bamboo seedlings. Under the treatment of $1 \mathrm{mmol} / \mathrm{L}$ and $0.5 \mathrm{mmol} / \mathrm{L}$ nitrogen, the nitrogen use efficiency reached higher, the photosynthesis rate and respiration rate were higher, and the nitrogen accumulation of stems was also higher. At this time, he seedling height and root length were the longest. The effects of different application sites on bamboo seedlings affect assimilation transport mechanism and the effect of nitrogen application on the morphological structure of bamboo seedling require further study.

\section{Acknowledgement}

This work was supported by the Twelfth Five-YearForestry Science and Technology Support Program of China (2015BAD04B03).The authors declare that they have no conflict of interest.

\section{References}

1. Zhang JX, Fang YQ Ding YF, Fang YM (2011) Chlorophyll content, photosynthetic parameters, and shade tolerance of ferns. Journal of Zhejiang University(Agriculture and Life Science) 37(4): 413-420.

2. Wagner BW, Beck E (1993) Cytokinins in the perennial herb Urtica dioica L.as influenced by its nitrogen status. Planta 190(4): 511-518.

3. Wang XY, Wang DM, Huang YZ (2011) Effects of AMF community on the growth and nutrient uptake of white clover at different $\mathrm{N}$ supply levels. Journal of Beijing Forestry University 2: 143-148

4. Liu FM, Li TF, Jiang J, Liu GF (2012) Selection of the optimum fertilizer formula and the effects of nutrient elements on growth and flowering performance of Betula platyphylla. Journal of Beijing Forestry University 2: $57-60$

5. Liu D, Yang XZ, Dai Silan, Wang JL (2014) Effects of nitrogen concentration on growth and flowering of standard chrysanthemum 'Ziruyi' under light-substrate cultivation. Journal of Beijing Forestry University 36(4): 106-110.

6. Xiao D, Wang XJ, Zhang K, Kang FF, He NP, et al. (2015) Effects of Nitrogen Deposition on Different Provenances of Acer Mono Maxim. Seedlings. Journal of Zhejiang University (Agriculture and Life Science 37(10): 50-57.

7. Xu QB, Guo BH, Fan SH, Su WH, Zhao JC (2014) Growth pattern of young bamboo under different management modes. Chinese Journal of Tropical Crops 35(8): 1481-1486.

8. Li WC, Wang SG, Wu ZZ, Zhou Y, Wang SD, et al. (2012) Plasticity responses of two sympodial bamboo species to nitrogen levels. Journal of Zhejiang University 38(5): 608-613.

9. Gu DX, Chen SL, Huang YQ (2011) Effects of soil nitrogen and phosphonium on leaf nitrogen and phosphonium stoichiometric characteristics and chlorophyll content of Oligostachyum lubbricum. Chinese Journal of Plant Ecology 35(12): 1219-1225.

10. Chen S, Chen SL, Guo ZW, Fan YR (2014) Leaf nutrient degradation due to mulching in a Phyllostachys violascens stand. Journal of Zhejiang
Agriculture and Forest University. Journal of Zhejiang Agriculture and Forest University 31(2): 272-279.

11. Guo ZW, Hu JJ, Yang QP, Li YC, Chen SL, et al. (2015) Influence of mulcing management on the relationship between foliar non-structural carbohydrates and N,P concentrations in Phyllostachys violascens stand. Chinese Journal of Applied Ecology 26(4): 1064-1070.

12. Chen GT, Tu LH, Peng Y, Hu HL, Hu TX, et al. (2017) Effect of nitrogen additions on root morphology and chemistry in a subtropical bamboo forest. Plant Soil 412: 441-451.

13. Chao JF, Gui RY, Ji HB, Li GD, Fang W (2011) A preliminary study on establishment of hydroponic culture system for Phyllostachys pubescens seedlings. Journal of Zhejiang Agriculture and Forest University 28(1): 86-94.

14. Rachel GMB, Werda S, Philippe S, Donald LS (2017) Root traits and nitrogen fertilizer recovery efficiency of corn grown in biochar-amended soil under greenhouse conditions. Plant Soil 415(1): 465-477.

15. Ryosuke F Neal Menzies (2017) Growth and yield response of glasshouse and field grown sweet potato to nitrogen supply .Nutrition Cycle Agroecosyst 108(3): 309-321.

16. Huang GB, Zhang Eand Hu HJ (2001) Eco-physiological mechanism on nitrogen use efficiency difference of corn varieties. Journal of Plant Nutrition and Fertilizer 7(3): 293-297

17. He F, Zhang H, Tang M (2016) Aquaporin gene expression and physiological responses of Robinia pseudoacacia $L$. to the mycorrhizal fungus Rhizophagus irregularis and drought stress. Mycorrhiza 26: 311323.

18. Liu T, Wang C, Chen H, Fang F, Zhu X, (2014) Effects of arbuscular mycorrhizal colonization on the biomass and bioenergy production of Populus $\times$ canadensis 'Neva' in sterilized and unsterilized soil. Acta Physiol Plant 36: 871-880.

19. Liu T, Sheng M, Wang CY, Chen H, Li Z, Tang M (2015) Impact of arbuscular mycorrhizal fungi on the growth, water status and photosynthesis of hybrid poplar under drought stress and recovery. Photosynthetica 53(2): 250-258.

20. Sultan SE (1992) What has survived of darwin's theory phenotypic plasticity and the neodarwinian legacy. Evolutionary Trends in Plants 6: 61-71.

21. Betzelberger AM, Gillespie KM, Mcgrath JM, Koester RP, Nelson RL, Ainsworth EA (2010) Effects of chronic elevated ozone concentration on antioxidant capacity, photosynthesis and seed yield of 10 soybean cultivars. Plant,Cell and Environment 33(9): 1569-1581.

22. Ye J, Ge GB, Ying YQ Xiang TT, Tao LH, et al. (2015) Study on absorption, accumulation and distribution of nutrient elements in overground part of bamboo. Journal of Plant Nutrition and Fertilizer 21(1): 164-170.

23. Marschner H, Kirkby E, Cakmak I (1996) Effect of mineral nutritional status on shoot-root partitioning of photoassilates and cycling of mineral nutrients. Journal of experimental botany 47: 1255-1263.

24. Wang Y (2003) Genotypic variation on N uptake and soluble sugar of three maize inbred lines in different nitrate treatment. Journal of Tianjin Agricultural College 10(3): 1-4.

25. Valladares F, Wright SJ, Lasso E, Kitajima K, Pearcy RW (2000) Plastic phenotypic response to light of 16 congeneric shrubs from a Panamanian rain forest. Ecology 81(7): 1925-1936.

26. Boucher JF, Pierre YB, Hank AM (2007) Growth and physiological response of eastern white pine seedings to partial cutting and site preparation. Forest Ecology and Management 240: 151-164.

27. Jiang LL, Han LS, Han XR, Zhan XM, Zuo RH, et al. (2011) Effects of nitrogen on growth, root morphological traits, nitrogen uptake and utilization efficiency of maize seedlings. Plant Nutrition and Fertilizer Science 17(1): 247-253. 


\section{ISSN: 2574-1241}

DOI: 10.26717/BJSTR.2019.15.002734

Li J. Biomed J Sci \& Tech Res

(c) $(7)$ This work is licensed under Creative

Submission Link: https://biomedres.us/submit-manuscript.php

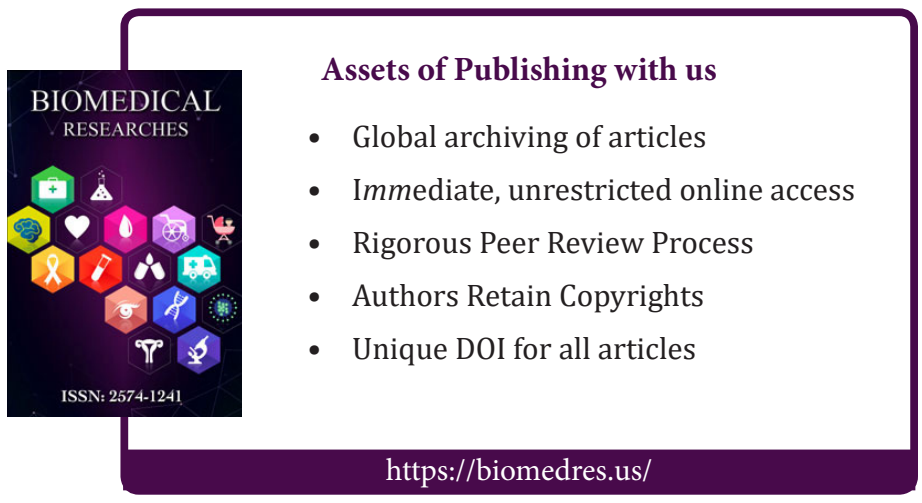

